\title{
Screening and selection of autochthonous fungi from leachate contaminated-soil for bioremediation of different types of leachate
}

\author{
Yassine Zegzouti ${ }^{1,2}$, Aziz Boutafda1, Loubna El Fels ${ }^{1,3^{\dagger}}$, Miloud El Hadek ${ }^{2}$, Fatou Ndoye ${ }^{4,5}$, \\ Nalla Mbaye ${ }^{4}$, Lamfeddal Kouisnii ${ }^{6}$, Mohamed Hafidi ${ }^{1,6}$ \\ ${ }^{1}$ Laboratory of Ecology and Environment (L2E), Cadi Ayyad University, Marrakesh, 40000, Morocco \\ ${ }^{2}$ Laboratory of Process Engineering Faculty of Sciences, Ibn Zohr University, Agadir, 80000, Morocco \\ ${ }^{3}$ Higher Institute of Nursing Professions and Health Technics, Marrakech-Safi, Morocco \\ ${ }^{4}$ Common Microbiology laboratory (IRD/ISRA/UCAD), Cheikh Anta Diop University of Dakar, Senegal \\ ${ }^{5}$ Laboratory of Phytochemistry and Plant Protection, Cheikh Anta Diop University of Dakar, 12500, Senegal \\ ${ }^{6}$ AgroBioSciences Program, Mohammed VI Polytechnic University (UM6P), Benguerir, 43150, Morocco
}

\section{ABSTRACT}

This study aims to use contaminated soil with leachate to select autochthonous fungi that are able to bioremediate three types of leachate, (Young $(\mathrm{YL})$, Intermediate (IL) and Old (OL)). Eleven fungal species were isolated via the enrichment method using the leachate as the sole source of carbon and energy. The isolates were evaluated for their ability to grow and remove organic pollutants at 100\%, 50\% and 25\% (v/v) of leachate in both solid and liquid cultures that were spiked with malt extract. The results indicated that only three fungi, Aspergillus flavus (A. flavus-LC106118), Aspergillus niger (A. niger-KT192262) and Fusarium solani (F. solani-KX349467) showed significantly high capacity to grow on leachate, with maximum radial growth rates $(\mathrm{Gr})$ of $7.5 \mathrm{~mm}, 4.7 \mathrm{~mm}$, and $5.3 \mathrm{~mm}$, respectively. In addition, $34 \%, 22 \%$, and $27 \%$, respectively of COD removal rates were obtained at $25 \%$ concentration in YL. A. flavus was the most tolerant fungus against landfill leachate, followed by $F$. solani, and finally A. niger. Therefore, these three fungi are good candidates for leachate bioremediation. However, for a better remediation, the combined effects of different types of fungi and leachates on the fungal growth need to be considered during the fungi selection.

Keywords: Autochthonous fungi, Bioremediation, Enrichment, Landfill, Leachate

\section{Introduction}

Leachate generation by municipal solid waste (MSW) landfills represents a serious environmental problem [1]. The leachate contains high concentration of organic and inorganic-based pollutants that could be classified into four groups [2, 3]: 1) Dissolved organic matter [measured by chemical oxygen demand (COD), total organic carbon (TOC), volatile fatty acids (VFA), more refractory compounds like fulvic-like, and humic-like compounds]; 2) inorganic macrocomponents [calcium $\left(\mathrm{Ca}_{2}{ }^{+}\right)$, magnesium $\left(\mathrm{Mg}_{2}{ }^{+}\right)$, sodium $\left(\mathrm{Na}^{+}\right)$, potassium $\left(\mathrm{K}^{+}\right)$, ammonium $\left(\mathrm{NH}_{4}^{+}\right)$, iron $\left(\mathrm{Fe}_{2}^{+}\right)$, manganese $\left(\mathrm{Mn}_{2}^{+}\right)$, chloride $\left(\mathrm{Cl}^{-}\right)$, sulphate $\left(\mathrm{SO}_{4}{ }^{2-}\right)$ and hydrogen carbonate $\left.\left(\mathrm{HCO}_{3}{ }^{-}\right)\right]$;
3) heavy metals [cadmium $\left(\mathrm{Cd}_{2}^{+}\right)$, chromium $\left(\mathrm{Cr}_{3}^{+}\right)$, copper $\left(\mathrm{Cu}^{2+}\right)$, lead $\left(\mathrm{Pb}^{2+}\right)$, nickel $\left(\mathrm{Ni}^{2+}\right)$ and zinc $\left.\left(\mathrm{Zn}^{2+}\right)\right]$; 4) xenobiotic organic compounds $\left(\mathrm{XOC}_{\mathrm{s}}\right)$, and other aromatic compounds that are usually present in relatively low concentration [4]. In general, three types of leachate have been defined according to landfill age: young, intermediate and old [1]. If the leachate discharge is not controlled and treated, it will cause serious environmental problems and pose a threat to the surrounding environment including soils, subterranean aquifers, and surface water [5]. Lately, a wide variety of chemical, physical, and biological technologies have been developed for the treatment of landfill leachate. These technologies include activated sludge (AS), sequencing batch reactors (SBR), re-
This is an Open Access article distributed under the terms of the Creative Commons Attribution Non-Commercial License (http://creativecommons.org/licenses/by-nc/3.0/) which permits unrestricted non-commercial use, distribution, and reproduction in any medium, provided the original work is properly cited.

Copyright (C) 2020 Korean Society of Environmental Engineers
Received July 25, 2019 Accepted October 14, 2019

${ }^{\dagger}$ Corresponding author

Email: loubna.elfels@gmail.com

Tel: +212524437665

ORCID: 0000-0002-1262-9354 
verse osmosis, and coagulation-flocculation [6, 7]. In the last two decades, nanotechnology has emerged and has been tested for almost all types of wastewater including landfill leachate [8-11]. The efficiency of the techniques used for wastewater treatment depends mostly on the efficiency of the material involved in the process [12-14]. In Morocco, the most common technologies used currently are natural evaporation, coagulation-flocculation and reverse osmosis [15]. Unfortunately, most of them have serious drawbacks, such as the low capacity in removing recalcitrant compounds, the formation of toxic by-products, operational problems due to equipment damage and malfunctioning, and their limited applicability to certain contaminants that are present at high level in the landfill leachate [2, 16]. In order to overcome these drawbacks, the bioremediation was introduced as an efficient and cost effective solution for removal of a wide variety of contaminants, including the ones present in landfill leachate $[17,18]$. Generally, the bioremediation is defined as a process that uses microorganisms or their enzymes to degrade the environmental contaminants into less toxic forms [19].

Currently, bacteria have been the most frequently used organisms in bioremediation applications [20, 21]. They can play an important role in understanding the uptake and potential removal behavior of heavy metals [22]. Certain filamentous fungi are also able to use pollutants as a growth substrate [23]. More than that, they show better degrading performance under environmentally stressful and fluctuating conditions such as extreme $\mathrm{pH}$, high salinity, inhibitors (e.g. ammonia), inadequate nutrient levels and the presence of toxic chemicals [24-27]. These features make the filamentous fungi good candidates for bioremediation in contaminated effluents [27]. A few studies were carried out using fungi for effective bioremediation of landfill leachates [2, 28-31]. Most of these studies have focused on non-autochthonous fungi, in particular white rot fungi such as Bjerkandera adusta MUT 2295, Ganoderm australe and Phanerochaete chrysosporium. In the same context, Ghosh and Thakur [32] reported that Phanaerochaete sp. ISTL01 reduced significantly the contaminant level on landfill leachate through biosorption. Certain autochthonous fungal isolated from the solid waste leachate are also potentially appropriate microbes for the bioremediation of landfill leachate [33, 34]. This could be due to their pre-adaptation to the harsh conditions which could be found in the landfill leachate [35, 36]. Only two studies conducted by Tigini et al. [33] and Spina et al. [17] used autochthonous fungi isolated from landfill leachate for landfill leachate treatment. However, in these studies the fungal treatment was applied without addressing the effect of the type of leachate together with its concentration. The variation in these two parameters may affect the treatment efficiency of the isolated fungi due to the heterogeneity and the complexity of the leachate since its inner composition could change with the age of the landfill [37-39]. On the other hand, despite the well-documented fungal presence in highly polluted soils, there are very few studies that dealt with autochthonous fungi in leachate-contaminated soil. Therefore, the present study was taken up to isolate, screen, and identify, efficient, strong and adaptable leachate autochthonous degrading fungi from leachate-contaminated soil sites through the enrichment method using the three most widely recognized landfill leachates - young, intermediate and old - at different concentrations. Afterwards, these fungi were investigated based on their ability to grow and remove organic pollutants.

\section{Materials and Methods}

\subsection{Site Description}

This study was conducted in Morocco in three different landfills: two are located in Marrakech city (Marrakesh Closed Landfill (MCL), and Al Mnabha village Marrakesh New Landfill (MNL)) and the other one in Agadir city (Greater Agadir landfill (GAL)), (Table 1). These locations were selected to be representative of landfills of different ages and types of waste. One of the three landfills (MCL) was non-controlled (without liners and leachate collection system), while the two others (MNL and GAL) were controlled (with liners and leachate collection systems). Among these three landfills, two were operational (MNL and GAL) while the third one was closed (MCL) but it is, currently, under re-planting operations.

\subsection{Sampling Procedure}

The leachate raw samples (YL, $\mathbb{L}$ and OL) and leachate contaminated

Table 1. General Conditions of the Landfill Sites Included in the Study

\begin{tabular}{lccc}
\hline Condition class & $\begin{array}{c}\text { Marrakesh New Landfill } \\
\text { (MNL) }\end{array}$ & $\begin{array}{c}\text { marrakesh closed landfill } \\
\text { (MCL) }\end{array}$ & $\begin{array}{c}\text { Greater agadir landfill } \\
\text { (GAL) }\end{array}$ \\
\hline $\begin{array}{l}\text { Landfill type } \\
\text { Period of landfilling }\end{array}$ & Sanitary (operational) & Non-sanitary (closed) & $\begin{array}{c}\text { Sanitary (operational) } \\
\text { (Mge of classification }\end{array}$ \\
$\begin{array}{l}\text { Aaily average of waste disposed (tonnage) } \\
\text { 2016-date }\end{array}$ & Young & $1980-2016$ & Old \\
Waste type & 900 to 1000 & 703 & Intermediate \\
Form of the leachate treatment & Household & Household, commercial and & Household \\
Fate of generated landfill gas & Physical and Biological & Physical & Physical and Biological \\
Coordinates at the landfill sites & No facility & No facility & No facility \\
\end{tabular}


soil samples were collected between February and March 2016 from the three above mentioned landfill sites with different ages, waste compositions, geographic settings, leachate productions and landfilling technologies.

\subsubsection{Leachate sampling}

As described by Kjeldsen and Christophersen [4], the three landfills were sampled directly from the leachate collection pond and from the leachate collection drains. Thus, there is no dilution with groundwater or surface water. Two grab leachate samples were taken from the main collecting drains, one from the leachate collection drain in the medium-aged GAL cell that received MSW from 2012 to 2016. The other sample was taken from the leachate collection drain in the young-aged MNL cell that was not yet capped, and had started to receive MSW (in 2016). In addition, in the MCL, composite leachate samples were taken randomly at three points in the untreated leachate collection pond in order to ensure sample representativeness and homogeneity [40]. The leachate samples were collected in clean polypropylene bottles, transported in a portable ice bag, and then preserved in the refrigerator APHA [41].

\subsubsection{Soil sampling}

The soil samples used in this study were obtained from the three landfills, MNL, MCL and GAL from a depth of 10-cm in moist soil [42]. The moist soil samples were taken from each landfill from different locations around the leachate collection ponds. The soil from the surrounding area of the landfill was already moistened and contaminated with leachate due to leakage from the waste cells. These three surrounding areas, as stated above, were contaminated with YL, OL and IL and were named in this paper MA1, MA2 and A1 sites, respectively. The soil samples were packed in sterilized ploybags and kept at $4^{\circ} \mathrm{C}$ in the laboratory. The freshly collected soil samples were homogenized by removing stones. The debris and the soil were sieved through 2-mm sieve plates for further analysis.

\subsection{Physico-chemical Characterization of Landfill Leachate}

The main physico-chemical charcteristics of landfill leachate originating from MNL, MCL and GAL were previously analyzed and discussed as shown by Zegzouti et al. [15]. The collected leachate samples were filtered through Whatman filter paper to remove suspended solids prior to measurement. The analytical procedures were conducted according to the Standard Methods for the Examination of Water and Wastewater APHA [41]. The analyses were performed for each sample in triplicates and the average values were taken. The suspended solids which were removed from the samples by filtration were weighted according to method 2540-D. The electrical conductivity (EC) and $\mathrm{pH}$ were measured by a CD-2005 conductivity meter and a $\mathrm{PH}-2006$ pH-meter, respectively. After oxidation with dichromate, the COD was determined by spectrophotometer (DR/2000 direct reading spectrophotometer) according to the Closed Reflux, colorimetric method (5220-B), while BOD measurements were performed following the Standard Method (5210). Total Kjeldahl Nitrogen (TKN) (4500-Norg C) was measured by Kjeldahl flask digestion followed by distillation and titration. The Distillation (4500-NH3 B) and the titrimetric
(4500-NH3 C) method were used to analyse the concentration of $\mathrm{NH}_{4}{ }^{+}-\mathrm{N}$. The $\mathrm{NO}_{3}^{-}-\mathrm{N}$ concentration was determined by the Devarda's Alloy Reduction Method APHA [43].

\subsection{Soil Enrichment Technique for Isolation of the Autochthonous Fungi}

After the serial enrichment culture technique, autochthonous heterotrophic filamentous fungi were isolated using the spread plating of soil suspensions technique [44]. For the enrichment culture, 10 grams of each of the three soil samples described above were aseptically inocultaed into $250 \mathrm{~mL}$ Erlenmeyer flasks containing $90 \mathrm{~mL}$ of Mineral Salts Medium (MSM) based on the composition described by Manjunatha and Kumar [45]. $0.1 \mathrm{~g} / \mathrm{L}$ of chloramphenicol was added to each sample to suppress bacterial growth. The MSM (in g/L distilled water) contains $\mathrm{NaCl}$ (10.0 g), $\mathrm{MgSO}_{4} .7 \mathrm{H}_{2} \mathrm{O}$ (0.42 g), KCl (0.29 g), $\mathrm{KH}_{2} \mathrm{PO}_{4}$ (0.83 g), $\mathrm{K}_{2} \mathrm{HPO}_{4}$ (0.9 g), $\mathrm{Na}_{2} \mathrm{HPO}_{4}$ (1.25 g), $\mathrm{NaNO}_{3}$ (0.42 g). The $\mathrm{pH}$ was adjusted to 7 . The broth medium was sterilized by autoclaving at $121^{\circ} \mathrm{C}$ for $20 \mathrm{~min}$. The medium solutions were spiked with $5 \%(\mathrm{v} / \mathrm{v})$ sterilized landfill leachate as the sole source of carbon (each culture flask was spiked with the same leachate type by which the soil sample is contaminated). The culture flasks were then incubated aerobically at $30^{\circ} \mathrm{C}$ on a rotary shaker at $140 \mathrm{rpm}$ for $7 \mathrm{~d}, 10 \%(\mathrm{v} / \mathrm{v})$ of these enriched cultures were transferred into same size culture flasks using the same fresh medium MSM 's compositions for the second enrichment as described by Kumar and Philip [46]. Hence, the enrichment of the culture consisted of three consecutive transfers, each having a span of $15 \mathrm{~d}$. At the end of the incubation period, $1 \mathrm{~mL}$ aliquots of the enrichment cultures of each soil sample were serially diluted up to $10^{-5}$ in sterile tubes of physiological saline with $0.8 \%(\mathrm{w} / \mathrm{v})$ solution of $\mathrm{NaCl}$. Afterwards, $1 \mathrm{~mL}$ aliquots were plated out onto the MSM agar medium enriched with $1 \%(\mathrm{v} / \mathrm{v})$ landfill leachate as the sole source of carbon and energy using the spread plate technique. The plates were then incubated in triplicate at $25^{\circ} \mathrm{C}$ for 7 to $10 \mathrm{~d}$. The MSM agar contained the same concentration of ingredients as mentioned above. It was prepared with the addition of agar at a concentration of $1.5 \%(\mathrm{w} / \mathrm{v})$ as a solidifying agent. Afterwards, the developed fungal colonies were picked and purified by repeated sub-culturing onto malt extract agar (MEA).

\subsection{Screening of Fungal Isolates for Growth and COD Removal in Leachate}

\subsubsection{Screening on solid media}

The fungal isolates that showed growth ability in the preliminary screening stage were examined for their capacity to be used in bioremediation of leachate using the method described by Lahlali and Hijri [47] and Razarinah et al. [36]. All the putative leachate utilizing fungal isolates were grown on a leachate-based agar medium under static condition. The culture medium contained malt extract agar (MEA) dissolved in the three types of the landfill leachate at various concentrations: $25 \%, 50 \%$ and $100 \%$. The medium was further autoclaved at $121^{\circ} \mathrm{C}$ for $20 \mathrm{~min}$ and the $\mathrm{pH}$ was adjusted to 7.00. Control plates were prepared by malt extract agar alone without the addition of leachate. 6- $\mathrm{mm}^{2}$ agar plugs cut out of actively growing fungal mycelia were taken using a cork borer from the 
edge of the fungal plate of each fungal isolate in 5 to $7 \mathrm{~d}$-old culture. They were placed in the center of the leachate-based agar medium described previously. The plates were incubated in triplicates at $28^{\circ} \mathrm{C}$. The growth of fungal isolates for each fungal isolates in the different treatments was evaluated by measuring every 48 $\mathrm{h}$ the radial growth of the fungal mycelia using a ruler over a period of $30 \mathrm{~d}$. The results were compared with the control. The radial growth rate was calculated by using the formula Gr (Eq. (1)) according to Dubey and Maheshwari [48]:

$$
\mathrm{Gr}=\frac{\left(\mathrm{R}_{1}-\mathrm{R}_{0}\right)}{\left(\mathrm{t}_{1}-\mathrm{t}_{0}\right)}
$$

Where, $R_{0}$ and $R_{1}$ are the colony radii at time $t_{0}$ and $t_{1}$, respectively. Gr, radial growth rate

\subsubsection{Screening isolates fungi for COD reduction}

The broth leachate-based medium used for the screening of fungal isolates for COD removal was prepared in the same way as specified above but without agar using the malt extract broth (MEB). This experiment was conducted in $250 \mathrm{~mL}$ Erlenmeyer flasks containing $100 \mathrm{~mL}$ of MEB medium. Four plugs (5- $\mathrm{mm}^{2}$ diameter) of a $7 \mathrm{~d}$-old of each fungal isolate colony growing on MEA media in Petri plates were transferred into the 250-mL Erlenmeyer culture flasks containing $100 \mathrm{~mL}$ of MEB spiked with 25\%, 50\%, and 100\% (v/v) of each landfill leachate. The $\mathrm{pH}$ of the media was adjusted to 7.00 before autoclaving using 1.0 M HC1 at room temperature. Inoculated flasks were then agitated on an orbital shaker for $30 \mathrm{~d}$ at $28 \pm$ $2^{\circ} \mathrm{C}$ and $150 \mathrm{rpm}$. A set of uninoculated flasks was similarly incubated to serve as controls. The ability of fungal isolates to reduce COD was measured after $30 \mathrm{~d}$.

\subsubsection{Statistical analysis of the data}

The statistical analysis was done with repeated measures analysis of variance (ANOVA) to evaluate the significant differences between treatments. In a first approach, two-way ANOVA was conducted to test the significant difference in the radial growth rate and COD removal rate of fungal isolates at $100 \%, 50 \%$ and $25 \%(\mathrm{v} / \mathrm{v})$ of $\mathrm{YL}, \mathrm{IL}$ and $\mathrm{OL}$ at 0.05 of significant level ( $\mathrm{p}<0.05$ ). The ANOVA was performed with fungal isolates obtained from A1 to A4, F1 to F4, P1 to P2 and M1. The types of leachate were used as factors and fungal radial growth and COD removal rates at 100\%, $50 \%$ and $25 \%(\mathrm{v} / \mathrm{v})$ were used as the dependent variables. Subsequently, Fisher's Least Significant difference (LSD) post-hoc tests were conducted on all data to prove if the differences between individual treatments at each level of concentration were significant $(\mathrm{p}<$ $0.05)$.

\subsection{Identification of Fungal Isolates}

\subsubsection{Preliminary identification}

Preliminary identification of these putative leachates utilizing fungal isolates was performed based on their morphological characteristics, including colony texture, colony colour, shape, size, mycelial type, and the conidiophores radial growth rate of colonies on PDA [49]. Microscopic examination of fungal spores by the slide culture technique was performed using the lactophenol cotton blue as a staining agent. The observed phenotypic and physiological charac- teristics of the fungal isolates were compared to the established identification key given in the "Manual of Soil Fungi" [50].

\subsubsection{Molecular identification of isolates}

\subsubsection{DNA extraction}

The DNA extraction procedure was adopted with slight modifications from Aamir et al.'s method [51]. The genomic DNA was extracted from 7 to $10 \mathrm{~d}$-old fungal cultures grown in a liquid medium (potato dextrose broth). The fungal mass was collected from the culture medium by filtration through four layers of sterile cheese cloth that allows the broth to pass through and retain the fungal mass. The obtained mass of fungal mycelium was placed into 1.5 -mL Eppendorf tubes containing 60-80 mg sterile glass beads and $800 \mu \mathrm{l}$ of lysis buffer (100 mM Tris HCl [pH8.0], 50 mM EDTA, 3\% SDS). The tubes were closed, mixed well to resuspend the glass beads, and were incubated in a water bath at $65^{\circ} \mathrm{C}$ for $10 \mathrm{~min}$. The resulting fungal tissue was centrifuged twice at 13,000 rpm for $10 \mathrm{~min}$. The supernatant was carefully transferred to a new tube and placed on ice for about $30 \mathrm{~s}$ to allow the fungal tissue to settle on the bottom of the tube. $2 \mathrm{~mL}$ of RNase solution (10 $\mathrm{mg} / \mathrm{mL}$ ) was added to the supernatant. The latter was incubated at $37^{\circ} \mathrm{C}$ for $15 \mathrm{~min}$. After the incubation and RNase treatment, an equal volume $(500 \mu \mathrm{l})$ of phenol: chloroform: Isoamyl alcohol (25:24:1) was added to the reaction mixture, mixed well, and centrifuged at 13,000 rpm for $10 \mathrm{~min}$. The top aqueous phase was carefully removed to a new tube and then an equal volume $(800 \mu \mathrm{l})$ of $100 \%$ ethanol was added. The tubes were gently mixed and incubated in a refrigerator for $2 \mathrm{~h}$ at $-20^{\circ} \mathrm{C}$ to allow the DNA to precipitate. The contents were centrifuged at $12.000 \mathrm{rpm}$ for 10 min to pellet down the DNA. Supernatant was discarded, and the DNA pellet was then washed twice with $800 \mu \mathrm{l}$ of chilled $70 \%$ ethanol and centrifuged at $12000 \mathrm{rpm}$ for $5 \mathrm{~min}$. The supernatant was removed and the pellet was air-dried at room temperature overnight until no ethanol was visible. The pellet was dissolved in $50 \mu \mathrm{l}$ of sterile $1 \times \mathrm{TE}$ buffer and stored at $-20^{\circ} \mathrm{C}$ for future use.

\subsubsection{PCR assay}

The extracted fungal genomic DNA was subjected to identification by PCR amplification of the ITS1-5.8S-ITS2 region of the different fungal isolates by using universal primers ITS1 (5'-TCCGTAGGTGA ACCTGCGG-3') and ITS4 (5'-TCCTCCGCTTATTGATATGC-3') [52] according to the following protocol: The PCR reaction for amplification of ITS1- 5.8S-ITS2 rDNA was performed in a total volume of $22 \mu \mathrm{l} .0 .3 \mu \mathrm{l}$ of each fungal DNA sample was added to the PCR master mixture prepared in a microtube. The 22 PCR mixture contained $2.5 \mu \mathrm{l}$ of $25 \mathrm{mM} \mathrm{MgCl}_{2}, 5 \mu \mathrm{l}$ of $5 \mathrm{X}$ PCR Buffers, $1 \mu \mathrm{l}$ of a deoxynucleoside triphosphate mixture (2.5 mM each dNTPs), $0.625 \mu \mathrm{l}$ of each primer $(20 \mu \mathrm{M}), 0.5 \mu \mathrm{l}$ BSA $(10 \mathrm{mg} / \mathrm{mL})$, and $0.3 \mu \mathrm{l}$ Go Taq buffer (Promega; Madison, USA), the total volume was completed with distilled water. The amplification was performed in the thermocycler programmed with the following thermal profile setup: initial denaturation at $95^{\circ} \mathrm{C}$ for $3 \mathrm{~min}$, followed by 35 cycles, with each cycle consisting of $5 \mathrm{~min}$ of denaturation at $95^{\circ} \mathrm{C}$, and 1 minute of hybridization at $58^{\circ} \mathrm{C}$. Reactions were completed with an initial 10 -min elongation time at $72^{\circ} \mathrm{C}, 1 \mathrm{~min}$ of elongation at $72^{\circ} \mathrm{C}$, followed by a final elongation at $72^{\circ} \mathrm{C}$ for $10 \mathrm{~min}$. The PCR product was subjected to electrophoresis on $1 \%$ 
agarose gel for $15 \mathrm{~min}$ sat $100 \mathrm{v}$. The gel was then stained with a solution of ethidium bromide (ETB), rinsed in sterilized water and observed under UV light on a Gel Doc 1000/2000 system.

\subsubsection{DNA sequencing}

The PCR products were sent to Inqaba Biotec Company (Pretoria, South Africa) for sequencing. The raw data from the sequencing were edited by using 4 peaks (http://4peaks.en.softonic.com/mac) and subjected to an identification using BLAST software (https://blast.ncbi.nlm.nih.gov/Blast.cgi) to compare nucleotide acid sequence similarities with the ITS1- 5.8S-ITS2 sequences of fungal species deposited in GenBank.

\section{Results and Discussion}

\subsection{Leachate Characterization}

The average values of different physico-chemical parameters of the MNL, MCL and GAL, respectively, are depicted in Table 2. As shown in this Table, the concentration of most of the measured parameters exceeded the permissible limits for direct discharge. The average $\mathrm{pH}$ values of leachates originating from MNL, MCL and GAL were 6.8, 9.1 and 8.1, respectively. The $\mathrm{pH}$ changed according to the age of the landfill [1]. Three types of leachate having different ages have been defined by Alvarez-Vazquez et al. [53] and Renoua et al. [1]. New landfills have generally a low $\mathrm{pH}(<6.5)$ whereas mature landfills have a high $\mathrm{pH}$ value $(>$ 7.5). The $\mathrm{pH}$ of intermediate landfills varied from 6.5 to 8 . This indicates that MNL, MCL and GAL could be classified as YL, OL and IL, respectively.

In this study, the highest value of COD was recorded in the MNL (19,523.3 $\mathrm{mg} / \mathrm{L})$ while the lowest value was recorded in the MCL $(9,517.4 \mathrm{mg} / \mathrm{L})$. This result shows that the MNL was highly charged with organic matter. On the other hand, the $\mathrm{BOD}_{5} / \mathrm{COD}$ ratio is considered as a good indicator of degradation of organic matter in landfill [54]. In the current study, the $\mathrm{BOD}_{5} / \mathrm{COD}$ ratios for leachate in the MNL, MCL and GAL were 0.6, 0.2 and 0.4, respectively. These results confirmed the previous conclusion about the possibility of categorizing MNL, MCL and GAL [1, 53]. As expected, the samples collected from MNL, MCL and GAL had high ammonia nitrogen content (5,931.3, 3,112.7 and 5,226.1 mg/L, respectively), which represents 80 to $90 \%$ of the total nitrogen contained in the landfill leachate [55]. Similar results were recorded at a landfill leachate in Tunisia [56]. In general, ammonia nitrogen is one of the most harmful wastewater contaminants due to its toxicity to microorganisms (e.g., its effect on mycelia growth and enzyme secretion). It also inhibits the biological treatment of leachate if it exceeds a certain concentration [57].

\subsection{Isolation and Culture Conditions of the Autochthonous Fungi}

Twenty-six autochthonous fungal isolates that grow using landfill leachate as sole source of carbon were successfully isolated from three different types of soil samples contaminated with different types of landfill leachates (YL, IL and OL). Based on macroscopic and microscopic morphological characteristics, the putative leachate utilizing fungal isolates were anamorphic basidiomycetes and ascomycetes, belonging to 8 different fungal genera. They were at genus level dominated by Aspergillus spp., Penicillum spp., Fusarium spp. and Mucor spp. Table 3 shows all the dominant fungal isolates species and their isolation frequencies in different contaminated soils. Out of the 26 fungal isolates, only eleven fungi exhibited good growth and different morphological features. They were numbered as A1, A2, A3, A4, F1, F2, F3, F4, P1, P2, and M. Among the isolated fungi, Aspergillus sp. had the highest frequency of isolation in each site, followed by Fusarium sp. in site MA1 and MA2, while Penicillium sp. recorded the second highest frequency of isolation in site MA2. The genera isolated in the three leachates belongs to the filamentous fungi family and is commonly present in soil [58]. As shown in Table 3, the $\mathrm{pH}$ of the soil was slightly alkaline (in the range 7.1 to 8.7 ). This range of $\mathrm{pH}$ was suitable for many alkali-tolerant fungi and impacted the type of fungi found in the three different sites [59]. This finding is in agreement with the $\mathrm{pH}$ values reported by Sebastião and Paulo [60]. These authors detected common soil fungi, such as Aspergillus sp., Penicillium sp. and Fusarium sp. that can grow in alkaline $\mathrm{pH}$ ranging from 7.7 to 8.2. In this study, the communities isolated from the three soil enrichment cultures were relatively similar to those isolated by Obire et al. [61] from soils that were collected from a waste dumpsite located at Eagle Island, Rivers

Table 2. Characteristics of Raw Leachate at Marrakesh (new and closed) and Greater Agadir Landfills (MNL, MCL and GAL). Values Represent Means \pm SD $(n=3)$ (Zegzouti et al. [15])

\begin{tabular}{|c|c|c|c|c|}
\hline \multirow{2}{*}{ No } & \multirow{2}{*}{ Parameter } & \multicolumn{2}{|c|}{ Marrakesh landfills } & \multirow{2}{*}{$\begin{array}{c}\text { Greater agadir landfill } \\
\text { Medium aged }\end{array}$} \\
\hline & & New & Old & \\
\hline & & Average & Average & Average \\
\hline 1 & $\mathrm{pH}$ & $6.8 \pm 0.1$ & $9.1 \pm 0.1$ & $8.1 \pm 0.04$ \\
\hline 2 & Electrical conductivity $(\mathrm{mS} / \mathrm{cm})$ & $66.8 \pm 0.1$ & $78.9 \pm 0.1$ & $55.4 \pm 0.04$ \\
\hline 4 & COD (mg/L) & $19,523.3 \pm 674.8$ & $9,517.4 \pm 375.1$ & $14,560.7 \pm 481.1$ \\
\hline 5 & $\mathrm{BOD}_{5}(\mathrm{mg} / \mathrm{L})$ & $11,600 \pm 700.3$ & $1,756.8 \pm 81.8$ & $5,300.2 \pm 2543$ \\
\hline 6 & $\mathrm{BOD}_{5} / \mathrm{COD}$ & $0.6 \pm 0.1$ & $0.2 \pm 0.02$ & $0.4 \pm 0.04$ \\
\hline 7 & Total Kjeldahl Nitrogen (TKN) & $6,335.2 \pm 390$ & $4,026.4 \pm 194.5$ & $6,149 \pm 239.1$ \\
\hline 8 & Ammonia-N (mg/L $\left.\mathrm{NH}_{4}{ }^{+}-\mathrm{N}\right)$ & $5,931.3 \pm 353$ & $3,112.7 \pm 203.54$ & $5,226.13 \pm 337.7$ \\
\hline
\end{tabular}


Table 3. Frequency of Leachate Tolerant Fungal Isolates. Values Represent Means \pm SD $(n=3)$

\begin{tabular}{|c|c|c|c|c|c|}
\hline Site code \% & Soil enrichment cultures types & pH soils & Organisms & FC Frequency \% & Total frequency $\%$ \\
\hline \multirow{4}{*}{ MA1 } & \multirow{4}{*}{ Young leachate-contaminated soil } & \multirow{4}{*}{$7.1 \pm 0.1$} & Aspergillus spp. & 50 & \multirow{4}{*}{89} \\
\hline & & & Fusarium spp. & 24 & \\
\hline & & & Penicillum spp. & 11 & \\
\hline & & & Mucor spp. & 4 & \\
\hline \multirow{4}{*}{ A1 } & \multirow{4}{*}{$\begin{array}{c}\text { Intermediate } \\
\text { leachate-contaminated soil }\end{array}$} & \multirow{4}{*}{$8.73 \pm 0.09$} & Aspergillus spp. & 70 & \multirow{4}{*}{92} \\
\hline & & & Penicillum spp. & 10 & \\
\hline & & & Fusarium spp. & 10 & \\
\hline & & & Mucor spp. & 2 & \\
\hline \multirow{4}{*}{ MA2 } & \multirow{4}{*}{$\begin{array}{l}\text { Old leachate-contaminated } \\
\text { soil }\end{array}$} & \multirow{4}{*}{$8.2 \pm 0.12$} & Aspergillus spp. & 40 & \multirow{4}{*}{78} \\
\hline & & & Penicillum spp. & 20 & \\
\hline & & & Fusarium spp . & 15 & \\
\hline & & & Mucor spp. & 3 & \\
\hline
\end{tabular}

State, Southern Nigeria and other soils that were collected by Awasthi et al. [62] from different MSW dumping sites in Jabalpur City, Madhya Pradesh (MP), India. In addition, the fungal community profiles obtained from these three enriched soils were remarkably similar even though the soil samples were obtained from different locations and were contaminated with different types of landfill leachate. This could be explained by the fact that fungi have a high dispersal potential. They can propagate through the dispersal of spores in the air and also help in maintaining the balance of a sustainable ecosystem in terms of ecological niche nutrient recycling, decomposing contaminants as well as symbiotic associations [25, 63]. Fungi can propagate in air over long distances by producing non-motile spores that may or may not be the product of mating between two compatible hyphae [64]. Presumably, the fungi isolated from these three contaminated soils possessed the catabolic potential necessary for the degradation of some organic compounds in landfill leachate [62]. Furthermore, they are generally able to tolerate the high toxicity and extreme physical parameters (i.e., high ammonia concentration), which is commonly found in landfill leachate. This could be explained by the progressing genetic drift which rapidly fixes alleles in small populations that conferred adaptation to harsh habitats, owing to the absence of sexuality and/or gene flow [33, 65]. Indeed, many extremophilic fungal species have mitotic lifestyle [33]. The number of fungi isolated from the enriched soil cultures was relatively low despite the use of the enrichment technique that could be considered as an efficient method for increasing the efficiency of the recovery of adequate active microbial population that is capable of tackling the specific contaminants and growing well in the pollutant-laden medium [44]. The low number of enriched fungal isolates that were observed visually could probably be due to high toxicity or mutagenicity of many chemical compounds present in the landfill leachates (YL, IL and OL), as previously mentioned, which may affect the metabolism and the diversity of soil biota. This could be related to the inhibitory effect of ammonia $(3,112.7-5,931.3 \mathrm{mg} / \mathrm{L})$ on fungal growth and enzyme secretion by fungi in landfill [56]. In general, the presence of leachate contamination significantly impacted the composition of the microbial community and their diversity in leachate- contaminated soil [66]. This finding suggests that the enriched fungal isolates may be used in landfill leachate as a sole source of carbon and energy under oligotrophic conditions of ammonia, salt concentration and high $\mathrm{pH}$.

\subsection{Screening of Fungal Isolates for Growth and Organic Pollutants Removal in Leachate}

\subsubsection{Screening on solid state culture}

As shown in Fig. 1, the radial growth rates of all fungal isolates supplemented with $25 \%, 50 \%$ and $100 \%$ (v/v) leachate were high on MEA without leachate. In general, each fungal isolate exhibited different maximum growth peaks. Moreover, the fluctuation of the growth of each fungus was observed when they were grown in various concentrations of landfill leachate. The two-way analysis of variance (ANOVA) confirmed these observations and indicated that there is a significant difference in fungal radial growth rates at $100 \%, 50 \%$ and $25 \%$ concentrations of leachate for the different types of isolated fungi and leachates. In addition, the same analysis revealed an interaction effect between types of fungal isolate and types of leachate. This suggests that the fungal radial growth rates obtained by the fungal isolates depend on the type of leachate used. Indeed, the fungal radial growth rates were higher for the fungal isolates when the leachate was young (Fig. 1(a)). Conversely, growth rates were lower for these fungal isolates when the leachate was old (Fig. 1(c)). Therefore, the combined effects of types of fungal isolates and types of leachates on the fungal growth rates have a significant impact on the selection of potential candidates for fungal leachate bioremediation. According to the Fisher's LSD tests, the fungal isolates A2, A3 and F2 had the highest growth rates on malt extract agar incorporated with $100 \%$ of the three aforementioned types of landfill leachate on the $30^{\text {th }}$ day with growth rates that are around 6/4.9/2.9 mm; 3.7/2.6/1.8 mm; and 4.2/3.8/2 mm, respectively in YL, IL and OL. As it was reported by Ellouze et al. [56], this result could be explained by the inhibitory and toxic effect of high ammonia levels (3,112.7-5,931.3 mg/L) in the three landfill leachates on fungal metabolism. A2 displayed high tolerance towards inhibitors of growth as it was the fungal 

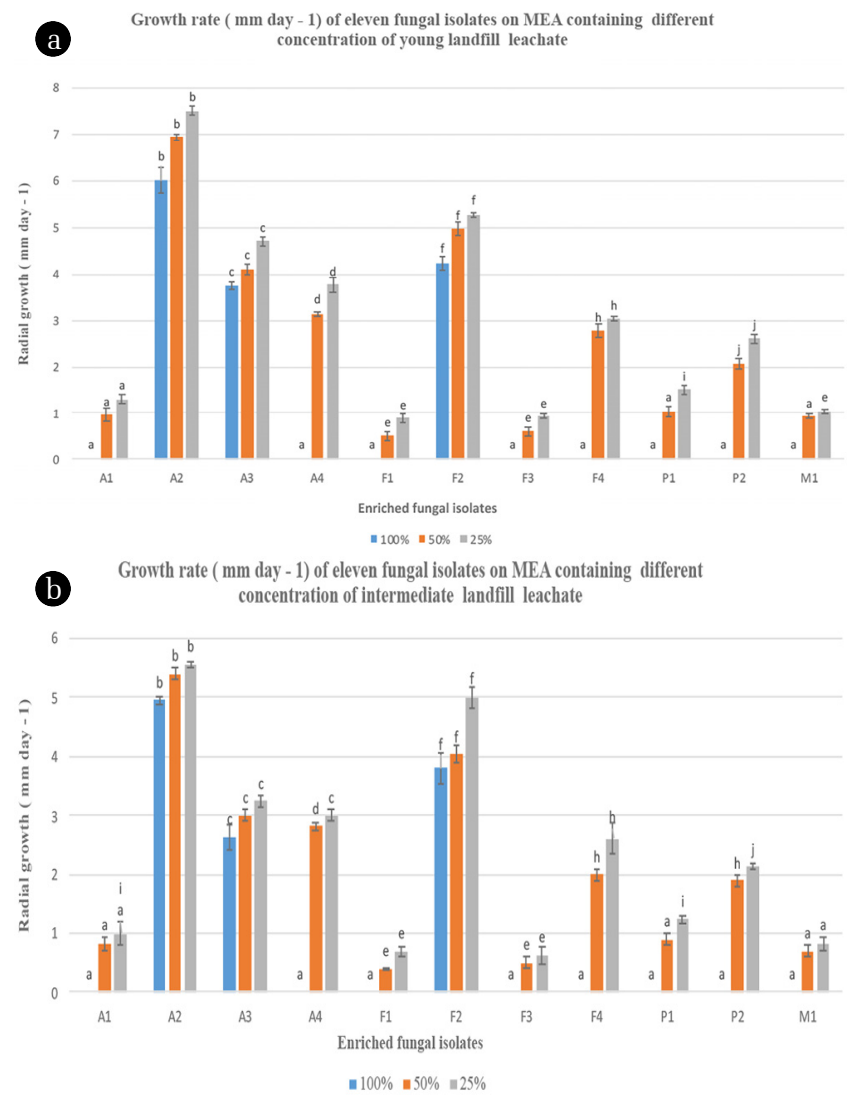

C Growth rate ( $\mathrm{mm}$ day - 1 ) of eleven fungal isolates on MEA containing different concentration of old landfill leachate

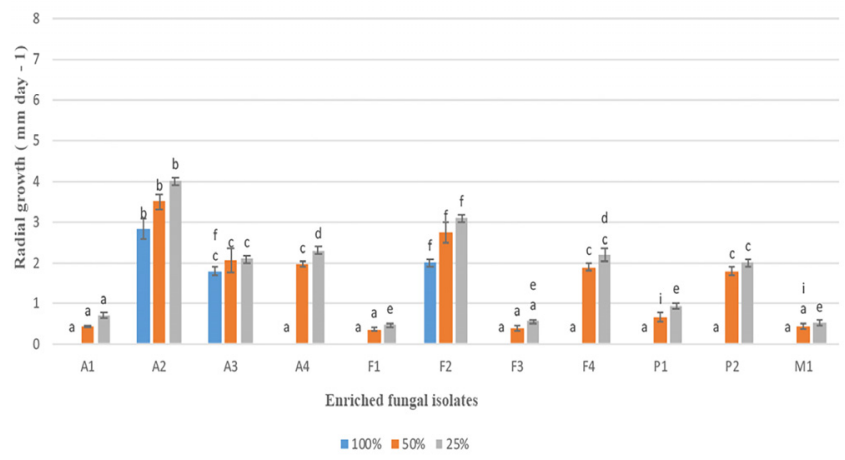

Fig. 1. Growth rate $\left(\mathrm{mm} \mathrm{d}^{-1}\right)$ of eleven fungal isolates on MEA with $100 \%, 50 \%$ and $25 \%$ of leachate at $28^{\circ} \mathrm{C}$. Different letters indicate significant differences between groups $(p<0.05)$. (a) Young leachate (YL). (b) Intermediate leachate (IL). (c) Old leachate $(\mathrm{OL})$. Error lines represent \pm standard deviation of the mean.

isolate that recorded the highest growth rate on MEA medium containing $100 \%$ (Fig. 3). The radial growth rate values recorded for A2, A3 and F2 in YL were higher than those obtained in the OL and IL. There was, indeed, a statistically significant difference with each other and with all the other fungal isolates in terms of fungal growth rates at each level of leachate concentration for each type of leachate (Fig. 1, p < 0.05). This might be due to the fact that $\mathrm{YL}$ (with high $\mathrm{BOD}_{5} / \mathrm{COD}$ ratio) contains large amounts of readily biodegradable organic matter (Table 2). As a result, the bioavailability of contaminants for biodegradation in the YL by the fungal isolates fungi may be increased [67]. Moreover, the OL (having low $\mathrm{BOD}_{5} / \mathrm{COD}$ ratio) might contain a considerable amount of recalcitrant compounds such as humic acids which are characterized by high molecular mass and, thus, are difficult to biologically degrade and be used as sole source of carbon by the tested fungal isolates [2]. This is attributed to the fact that many high-molecular-weight compounds fail to penetrate the cell membrane and are also not altered by extracellular enzymes [68]. The screening of fungi for their ability to grow on landfill leachate incorporated with MEA has previously been studied by Razarinah et al. [69]. These authors showed that the highest growth rate was recorded for Ganoderma australe, Trametes menziesii (KUM 7011(54)) and Penicillium sp on MEA containing $100 \%$ of landfill leachate. The growth rates of these fungi were $6.1 \mathrm{~mm}, 5.9 \mathrm{~mm}$ and $2.3 \mathrm{~mm}$, respectively. These values were relatively higher than those obtained in the current study. This could be related to the fact that the use of white rot fungi has often displayed a high ability to degrade and mineralize a wide range of recalcitrant pollutants in stressing environmental conditions [70]. However, the use of microorganisms autochthonous to the contaminated site was proven to be one of the most powerful tools for bioaugmentation when compared to the introduced microorganisms [44]. This is due to their quick ability to adapt and their efficiency to use contaminants of interest within a reasonable period of time [71]. Comparative assessment, based on the radial growth of fungal mycelia on $50 \%$ and 25\% leachate spiked with MEA, showed that all the fungal isolates fungi grew successfully. For example A4, P2 and F4 had radial growth rates of 3.1, $2.8 \mathrm{~mm} ;(2,1.9) \mathrm{mm}$; and $(2.7,2) \mathrm{mm}$ in $50 \%(\mathrm{v} / \mathrm{v})$ YL and IL, respectively. Lakhtar et al. [72] reported a satisfactory growth rate of four strains of Lentinula edodes on PDA containing $10 \%$ and $20 \%$ (v/v) of olive mile wastewater (OMW). Generally, the high radial growth rates for the fungal isolates could be associated to the dilution effect of the distilled water .Generally, dilution is considered a mechanism by which pollutants concentration can be attenuated [73]. This dilution effect on the fungal strains growth was observed by Razarinah et al. [36] and Lakhtar et al. [72]. However, these radial growth rates values were lower than expected since higher values are usually obtained at low concentration. This might be the consequence of the low bioavailability of the contaminants present in at lower concentration $25 \%$ $(\mathrm{v} / \mathrm{v})$, which governs the rate of biodegradation. This could also be explained by the fact that fungal cells expend energy to induce catabolic gene systems used in biodegradation [67].

\subsubsection{Performance of fungal isolates for $C O D$ reduction}

Screening of leachate utilizing fungal isolates for organic pollutants removal was conducted in liquid stirred cultures. The eleven fungal isolates were grown on liquid leachate-based media using three different types of leachate at different concentrations of leachate $(25 \%, 50 \%$, and $100 \%(\mathrm{v} / \mathrm{v}))$ spiked with malt extract. The results showed different organic matter removal capabilities among the eleven fungal isolates as exhibited in Fig. 2. Most of these fungal isolates showed remarkably decrease COD removal levels by increasing leachate concentration, whereas no reduction in COD was detected for the non-inoculated medium (control). However, from 

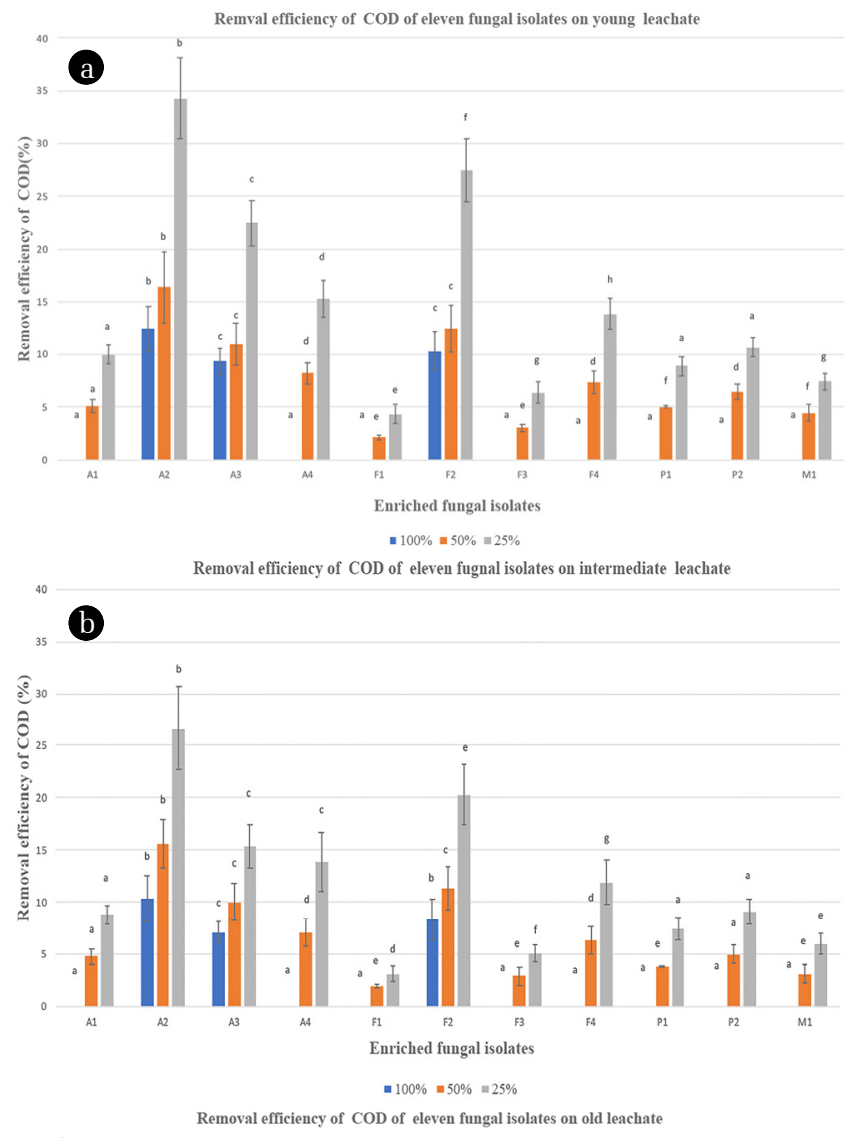

c

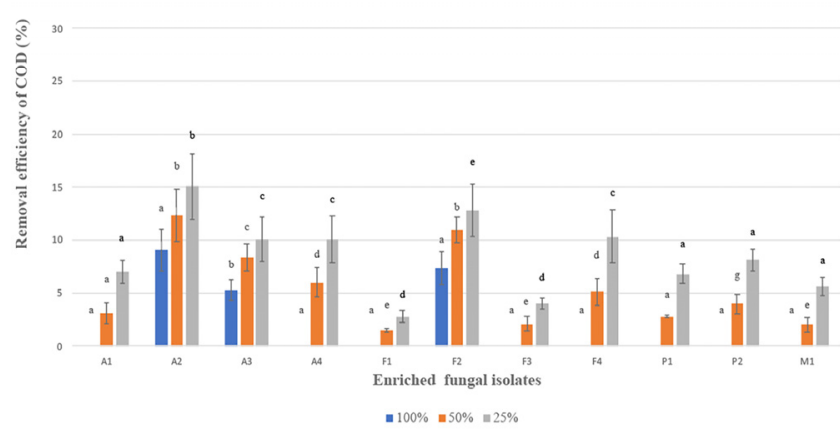

Fig. 2. COD removal efficiency (\%) of eleven fungal isolates on MEB spiked with $100 \%, 50 \%$ and $25 \%$ of leachate at $28^{\circ} \mathrm{C}$. Different letters indicate significant differences between groups ( $p<0.05)$. (a) Young leachate (YL). (b) Intermediate leachate (IL). (c) Old leachate $(\mathrm{OL})$. Error lines represent \pm standard deviation of the mean.

the obtained results, it is clear that only some isolates (e.g., A2, F2 and A3) have a high organic matter removal at $100 \%$ concertation of leachate. This could be attributed to the fact that leachate may be toxic to fungal isolates at high concentration, thereby, inhibiting the growth of fungal isolates [56]. Koutrotsios and Zervakis [74] reported similar results by assessing the growth of several wood-rot macro fungi in the presence of olive mill wastewater (OMWW).

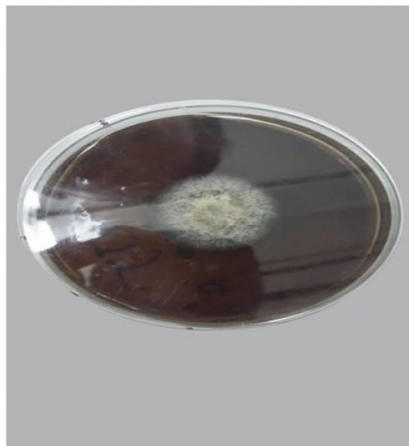

(a) Fungal isolate A2 on $100 \%$ YL (5 d)

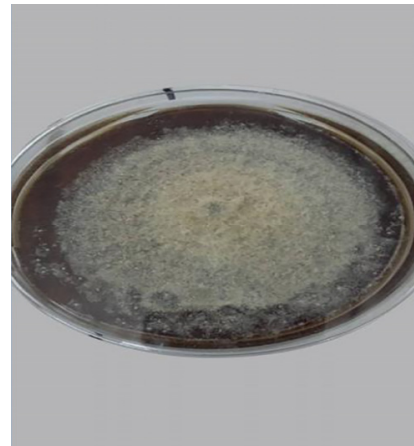

(b) Fungal isolate A2 on $100 \%$ YL $(20 \mathrm{~d})$
Fig. 3. Growth of fungal isolates A2 on MEA incorporated with $100 \%$ leachate after (a) $5 \mathrm{~d}$ and (b) $20 \mathrm{~d}$ of incubation at $25^{\circ} \mathrm{C}$, respectively.

They showed that only a few fungi were able to grow adequately on liquid media containing $100 \%$ (v/v) OMWW because of its inhibitory and toxic effect on fungal growth. In general, undiluted leachate $(100 \%(\mathrm{v} / \mathrm{v}))$ seems to not be relatively suitable for fungal isolates growth. However, significant organic matter removal rates were obtained in low concentrated leachate. For example, out of the eleven fungal isolates, A2, and F2 and A3 showed the highest reduction of COD with maximum removal rates of around $34 \%$, $27 \%$ and $22 \%$, respectively at $25 \%$ of YL (Fig. 2(a)). Similar results, in terms of COD reduction (32\%), have been reported in a study on landfill leachate by immobilized Ganoderma austral. In another study, $48 \%$ removal of COD was obtained in raw leachate using B. adusta in batch tests, with biomass cultivated in encapsulated form on polyurethane foam cubes (PUFs) [2]. Thus, these three fungi (A2, F2 and A3) were able to decrease remarkably the organic matter present in the landfill leachate compared with other isolates, especially when they were grown in YL. This could be explained by the fact that Young leachate contains large amounts of low molecular weight and easily biodegradable organic compounds [75]. In contrast, these isolates were found to be less effective in reducing COD in both $\mathrm{IL}$ and $\mathrm{OL}$ as compared to $\mathrm{YL}$ at $25 \%$ (v/v) leachate (Fig. 2(b), (c)). This suggests that the types of leachate had a significant effect on the COD reduction for within each type of leachate. The two-way analysis of variance (ANOVA) confirmed these results and revealed a significant effect of the types of fungal isolates and the types of leachate on fungal COD reduction (Fig. 2, p < 0.05). At 50\% concentration, the COD reduction for A2, A3 and F2 followed the same trend as the one at $25 \%$, with a maximum rate of $16 \%, 11 \%$ and $12 \%$, respectively in YL. These results indicated the favorable effect of dilution, since high COD reduction were observed at $50 \%$ and $25 \%(\mathrm{v} / \mathrm{v})$ leachate concentrations as compared to $100 \%(\mathrm{v} / \mathrm{v})$. The results are in agreement with previous findings that showed a satisfactory growth rate of several strains on $50 \%$ (v/v) OMW [74]. These results highlight also the importance of the use of autochthonous fungi for leachate treatment which has been confirmed very recently by Spina et al. [17] that has achieved a good and very fast decolorization percentage $(60 \%)$ coupled with detoxification for landfill leachate by two autochthonous fungi called Pseudallescheria boydii MUT 721 and 
Phanerochaete sanguine MUT 1284. Unsurprisingly, the COD reduction of the other fungal isolates such as M1, P1 and F3 was very low in the three leachates with maximum values of $7 \%, 9 \%$ and $6 \%$, respectively. These low values could be attributed to the different metabolic pathways leading to the removal of organic matters with difference microorganisms.

\subsection{Fungal Characterization and Molecular Identification}

The three suitable fungi for utilizing and degrading landfill leachate (YL, IL and OL) A2, A3 and F2 were identified using morphological traits and molecular biology. As stated in the previous section, the morphological characterization of these suitable fungal isolates showed that F2 species belong to the genera Fusarium sp., while

Table 4. Macroscopic and Microscopic of the Three Suitable Fungal Isolates Utilizing and Degrading Landfill Leachate

\begin{tabular}{ll}
$\begin{array}{l}\text { Fungal } \\
\text { isolates }\end{array}$ & Plate \\
\hline A2 & Presumed as Aspergillu sp. \\
\hline
\end{tabular}

Colony was fast growing, and Petri dishes were not completely covered with mycelium after 4 weeks in a $25^{\circ} \mathrm{C}$ oven. Aerial mycelium was entirely green on the surface but sometimes
Presumed as Aspergillus sp.

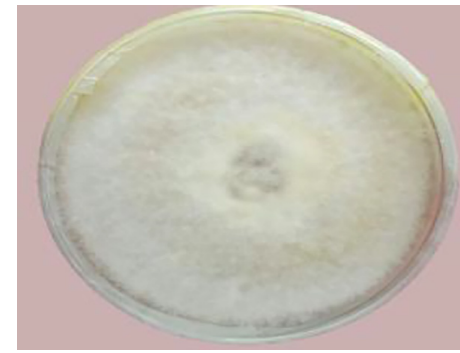

The color of the mycelium was blackish on the surface, with a powdery appearance. On the base of the Petri dish, the color of the mycelium was also blackish with whitish patches intended to appear over the entire but sometimes was blackish on its periphery.

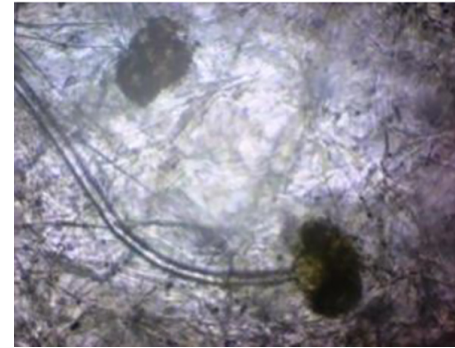

Magnification G 400

The observation showed that the conidiophore had subglobose and rough vesicles. The spores form was more or less spherical.

Presumed as Fusarium sp.

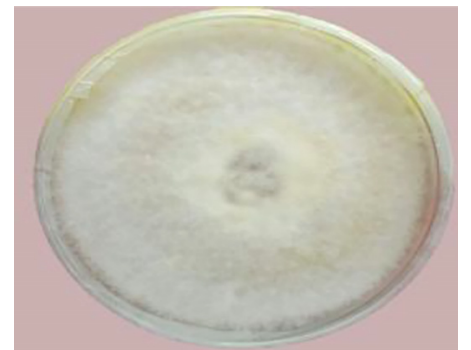

Colony was fast growing, and Petri dishes were not completely covered with mycelium after 4 weeks in a $25^{\circ} \mathrm{C}$ oven. Aerial mycelium was entirely yellowish on the surface but sometimes with whitish areas and especially downy in appearance.

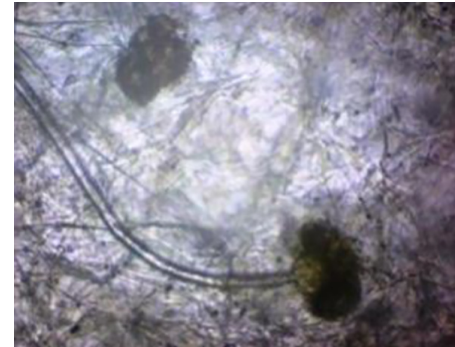

Magnification G 400

The conidiophores were repeatedly branched and had a globose and black head. The spores of these fungi were small and black. 
Table 5. Fungal Taxa Isolated From Contaminated Landfill Leachate Based on the Closest Blast Match of Fungal ITS Sequence

\begin{tabular}{|c|c|c|c|c|c|}
\hline \multirow{2}{*}{ Isolate ID } & \multirow{2}{*}{ Phylum class } & \multicolumn{3}{|c|}{ Closest blast } & \multirow{2}{*}{$\begin{array}{l}\text { Site } \\
\text { code }\end{array}$} \\
\hline & & Strain & Genbank accesion no. & \% Identity & \\
\hline A2 & Eurotiomycetes & Asperglius flavus & LC106118 & 99 & A \\
\hline A3 & Eurotiomycetes & Aspegillus niger & KT192262 & 99 & MA1 \\
\hline $\mathrm{F} 2$ & Sordariomycetes & Fusarium solani & KX349467 & 99 & A \\
\hline
\end{tabular}

A2 and A3 belonged to Aspergillus sp. (Table 4). As shown in Table 5, the molecular identification of the three fungal isolates using ITS-1 and ITS-2 primers further confirmed that these isolates were Asperglius flavus (A flavus) (LC106118), Aspegillus niger (A. niger) (KT192262) and Fusarium solani (F. solani) (KX349467), respectively, as shown in Table 5. Generally, Aspergillus species are filamentous fungi that are frequently found in soil and decaying vegetation and grains where they thrive as saprophytes [76]. These species are more tolerant to alkaline conditions, in particular $A$. niger and $A$. flavus that are reported to be able to grow over a wide range of $\mathrm{pH}$ (1.4 to 9.8 and 4 to 9 , respectively) [77, 78]. Thus, they could be good candidates for landfill leachate bioremediation that has a $\mathrm{pH}$ ranging from 4.5 to 9 [79]. Aspergillus species, especially $A$. niger and $A$. flavus have been well known for their potential application in bioremediation of effluents with different strengths from different landfills, industries and sewage [80]. Other studies have also shown the applicability of fungi species such as $A$. niger and $A$. flavus for the biodegradation of various contaminants including heavy metals, textile dyes and crude oil contaminants [81-84]. Furthermore, Fusarium species, a saprotrophic fungus belonging to the phylum Ascomycota are well-distributed soil inhabitants and are often associated with plant roots saprophytes [85]. These species have also been reported to tolerate alkaline conditions [86]. Some Fusarium species such as F. solani, which were investigated in the present study, were found suitable for landfill leachate bioremediation. They have shown high tolerance and a good ability to degrade a wide range of recalcitrant substances [87]. In addition, Fusarium $s p$. are known to remove a plethora of high-molecular-weight compounds such as hydrocarbons, cellulose and coal [88].

\section{Conclusions}

The obtained results showed that out of the eleven fungal isolates, only three autochthonous fungi; Aspergillus flavus (A2), Aspergillus niger (A3) and Fusarium solani (F2) showed the highest radial growth rate and COD removal efficiency at 25\%, 50\%, and $100 \%$ (v/v) of the three types of leachate (young, intermediate and old). Therefore, they have been the most suitable candidates for bioremediation for these three different types of landfill. In particular, Aspergillus flavus (A2) was the most tolerant against landfill leachate as it exhibited the highest radial growth rate $(7.5 \mathrm{~mm})$ and COD reduction (34\%) at $25 \%$ concentration of young leachate. Fusarium sp. (F2) and Aspergillus niger were classified after Aspergillus flavus (A2) in terms of organic removal abilities with a maximum of COD reduction of $27 \%$ and $22 \%$, respectively on $25 \%$ young leachate. These results highlight also the importance of the use of autoch- thonous fungi for leachate treatment. However, more investigations need to be done in order to fully understand the mechanism involved in the acclimatization of these unfavorable environmental conditions and to describe the main metabolic pathways used to adapt to these conditions.

\section{Author Contributions}

Y.Z. (Dr) did methodology, data curation, writing- original draft preparation, laboratory analysis. A.B. (Student) did sampling, laboratory analysis. L.E.F. (Professor) did conceptualization, methodology, data curation, writing- original draft preparation, editing. F.N. (Dr) and N.M. (Dr) did molecular identification of isolate strains.M.H. did methodology, correction, supervised. M.E.H. (Professor) did co-supervisor. L.K. (Professor) did English correction.

\section{References}

1. Renou S, Givaudan JG, Poulain S, Dirassouyan F, Moulin P. Landfill leachate treatment: Review and opportunity. J. Hazard. Mater. 2008;150:468-493.

2. Bardi A, Yuan Q, Tigini V, et al. Recalcitrant compounds removal in raw leachate and synthetic effluents using the white-rot fungus Bjerkandera adusta. Water 2017;9:824.

3. Quasim S, Chiang W. Sanitary landfill leachate: Generation, control and treatment. Lancaster: Technomic Publication; 1994. p. $129-146$.

4. Kjeldsen P, Christophersen M. Composition of leachate from old landfills in Denmark. Waste Manage. 2001;19:249-256.

5. Aziz HA, Adlan MN, Amilin K, Yusoff MS, RamLy NH, Umar M. Quantification of leachate generation rate from a semi-aerobic landfill in Malaysia. Environ. Eng. Manage. J. 2012;11:1581-1585.

6. Alijani-Ardeshir R, Rastgar S, Peyravi M, Jahanshahi M, Shokuhi-Rad A. A new route of bioaugmentation by allochthonous and autochthonous through biofilm bacteria for soluble chemical oxygen demand removal of old leachate. Environ. Technol. 2017;38:2447-2455.

7. Inoue K, Uffink GJ, Kobayashi A, Tanaka T. Health risk assessment for a leachate plume from a landfill under different hydrogeological conditions. J. Rain. Catch. Syst. 2011;16:1-12.

8. Saleh TA. Mercury sorption by silica/carbon nanotubes and silica/activated carbon: A comparison study. J. Wat. Sup. Res. Tech. 2015;64:892-903.

9. Saleh TA. An overview of nanomaterials for water technology. In: Advanced nanomaterials for water engineering treatment 
and hydraulics; 2017. p. 1-12.

10. Zaidi Ab G, Yusoff MS, Andas J. Review on applications of nanoparticles in landfill leachate treatment. In: Applied mechanics and materials. Appl. Mech. Mater. 2015. p. 525-530.

11. Saleh TA, Ali I. Synthesis of polyamide grafted carbon microspheres for removal of rhodamine B dye and heavy metals. J. Environ. Chem. Eng. 2018;6:5361-5368.

12. Saleh TA. Nanocomposite of carbon nanotubes/silica nanoparticles and their use for adsorption of $\mathrm{Pb}$ (II): From surface properties to sorption mechanism. Desalin. Water. Treat. 2016;57:10730-10744.

13. Ali I, AL-Hammadi SA, Saleh TA. Simultaneous sorption of dyes and toxic metals from waters using synthesized titania-incorporated polyamide. J. Mol. Liq. 2018;269:564-571.

14. JamJam NM, Yap YH, Muhamad EN, Saiman MI, Saleh TA. Free solvent oxidation of molecular benzyl alcohol by newly synthesized AuPd/titania catalysts. Inorg. Chem. Commun. 2019;107:107471.

15. Zegzouti Y, Boutafda A, El-Fels L, et al. Quality and quantity of leachate with different ages and operations in semi-arid climate. Desalin. Water. Treat. 2019;152:174-184

16. Atab MS, Smallbone AJ, Roskilly AP. An operational and economic study of a reverse osmosis desalination system for potable water and land irrigation. Desalination 2016; 397:174-184.

17. Spina F, Tigini V, Romagnolo A, Varese G. Bioremediation of landfill leachate with fungi: Autochthonous vs. allochthonous strains. Life 2018;8:27.

18. Spina F, Varese GC. Fungal bioremediation of emerging micropollutants in municipal wastewaters. In : Fungal applications in sustainable environmental biotechnology. New York: Springer; 2016. p. 115-141.

19. De Lorenzo V. Systems biology approaches to bioremediation. Cur. Opin. Biotechnol. 2008;19:579-589.

20. Todorova IT, Kostova IS. Bioremediation of leachate in the landfill drainage system. Biotechnol. Biotechnol. Equip. 2000;14:65-71.

21. Morris S, Cabellos G, Enright D, Ryan D, Enright AM. Bioremediation of landfill leachate using isolated bacterial strains. Int. J. Envir. Biorem. Biodegard. 2018;6:1-4.

22. Aljerf L, AlMasri N. A gateway to metal resistance: Bacterial response to heavy metal toxicity in the biological environment. Ann. Adv. Chem. 2018;2:32-44.

23. Ren Y, Yuan Q. Fungi in landfill leachate treatment process. Biodegradation and bioremediation of polluted systems. New advances and technologies; 2015. p. 1-16.

24. Mollea C, Bosco F, Ruggeri B. Fungal biodegradation of naphthalene: Microcosms studies. Chemosphere 2005;60:636-643.

25. Harms H, Schlosser D, Wick LY. Untapped potential: Exploiting fungi in bioremediation of hazardous chemicals. Nat. Rev. Microbiol. 2011;9:177-192.

26. Joshi R, Pant D. Landfill biodegradation process and leachate. In: Waste Bioremediation. New York: Springer; 2018. p. 233-247.

27. Ellouze M, Aloui F, Sayadi S. Performance of biological treatment of high-level ammonia landfill leachate. Environ. Technol. 2008;29:1169-1178

28. Ellouze M, Aloui F, Sayadi S. Detoxification of Tunisian landfill leachates by selected fungi. J. Hazard. Mater. 2008;150:642-648.

29. Wan Razarinah W, Noor Zalina M, Abdullah N. In: Screening method for selecting the potential fungi for use in the bioremediation of leachate 2nd International Conference. Environ. Sci. Technol. 2011:191-194.

30. Tigini V, Spina F, Romagnolo A, Prigione V, Varese GC. Effective biological treatment of landfill leachates by means of selected white rot fungi. Chem. Eng. Trans. 2013;32:265-270.

31. Smaoui Y, Fersi M, Mechichi T, Sayadi S, Bouzid J. A new approach for detoxification of landfill leachate using Trametes trogii. Environ. Eng. Res. 2019;24:144-149.

32. Ghosh P, Thakur IS. Biosorption of landfill leachate by Phanerochaete sp . ISTL01: isotherms, kinetics and toxicological assessment. Environ. Technol. 2017;38:1800-1811.

33. Tigini V, Prigione V, Varese GC. Mycological and ecotoxicological characterisation of landfill leachate before and after traditional treatments. Sci. Total Environ. 2014;487:335-341.

34. Godoy P, Reina R, Calderón A, Wittich RM, García-Romera I, Aranda E. Exploring the potential of fungi isolated from PAH-polluted soil as a source of xenobiotics-degrading fungi. Environ. Sci. Pollut. Res. 2016;23:20985-20996.

35. Vogel TM. Bioaugmentation as a soil bioremediation approach. Curr.Opin. Biotechnol.1996;7:311-316.

36. Wan Razarinah W, Noor Zalina M, Abdullah N. Screening method for selecting the potential fungi for use in the bioremediation of leachate. In: 2nd International Conference. Envi. Sci and Tech. 2011:191-194.

37. Rosqvist HN, Dollar HL, Fourie BA. Preferential flow in municipal solid waste and implications for long-term leachate quality: Valuation of laboratory-scale experiments. Waste Manag. Res. 2005;23:367-380.

38. Scandelai APJ, Sloboda Rigobello E, Oliveira BLC, et al. Identification of organic compounds in landfill leachate treated by advanced oxidation processes. Environ. Technol. 2019;40: 730-741.

39. Žgajnar Gotvajn A, Derco J, Tišler T, Cotman M, Zagorc-Končan J. Removal of organics from different types of landfill leachate by ozonation. Water Sci. Technol. 2009;60:597-603.

40. Kjeldsen P, Bjerg PL, Rügge K, Christensen TH, Pedersen JK. Characterization of an old municipal landfill (Grindsted, Denmark) as a groundwater pollution source: Landfill hydrology and leachate migration. Waste Manage. Res. 1998;16:14-22.

41. APHA. Standard Method for the Examination of water and wastewater. Washington D.C.: American Public Health Association; 1998.

42. Masngut N, Manap S, Che MR, Shaarani S. Bacteria isolation from landfill for production of industrial enzymes for waste degradation. Indian J. Sci. Technol. 2017;10:1-5.

43. APHA. Standard method for the examination of water and wastewater. 19th eds. Washington D.C.: American Public Health Association; 1995.

44. Philp JC, Atlas RM. Bioremediation of contaminated soils and aquifers. In: Bioremediation. American Society of Microbiology; 2005. p.139-236.

45. Manjunatha PK, Kumar BK. Isolation of diesel, engine oil and crude oil degrading fungi from oil contaminated soil for their bioremediation potential. J. Agric. Food Nat. Resour. 2017;1:65-70.

46. Kumar M, Philip L. Bioremediation of endosulfan contaminated soil and water-optimization of operating conditions in laboratory 
scale reactors. J. Hazard. Mater. 2006;136:354-364.

47. Lahlali R, Hijri M. Screening, identification and evaluation of potential biocontrol fungal endophytes against Rhizoctonia solani AG3 on potato plants. FEMS Microbiol. Lett. 2010;311:152-159.

48. Dubey RC, Maheshwari DK. Practical microbiology. S. Chand Pvt. Limited; 2012. p. 160-183

49. Promputtha I, Jeewon R, Lumyong S, et al. Ribosomal DNA fingerprinting in the identification of non sporulating endophytes from Magnolia liliifera (Magnoliaceae). Fungal Divers. 2005;20:167-186.

50. Gilman JC, Joseph C. A manual of soil fungi. New Delhi: Daya Publishing House; 1998. p. 56-70.

51. Aamir S, Sutar S, Singh SK, Baghela A. A rapid and efficient method of fungal genomic DNA extraction, suitable for PCR based molecular methods. Plant Pathol. Quar. 2015;5:74-81.

52. White T, Bruns T, Lee S, et al. Amplification and direct sequencing of fungal ribosomal RNA genes for phylogenetics. PCR protocols: A guide to methods and applications. 1990;18:315-322.

53. Alvarez-Vazquez H, Jefferson B, Judd SJ. Membrane bioreactors vs conventional biological treatment of landfill leachate: a brief review. J. Chem. Technol. Biotechnol. 2004;79:1043-1049.

54. Lee AH, Nikraz H. BOD: COD Ratio as an indicator for pollutants leaching from landfill. J. Clean Energ. Technol. 2014;2:263-266.

55. Robinson HD, Barr MJ, Last SD. Leachate collection, treatment and disposal. Water Environ. J. 1992;6:321-332.

56. Ellouze M, Aloui F, Sayadi S. Effect of high ammonia concentrations on fungal treatment of Tunisian landfill leachates. Desalination 2009;246:468-477.

57. Gotvajn AŽ, Pavko A. Perspectives on biological treatment of sanitary landfill leachate. In: Wastewater treatement engineering. InTech; 2015. p. 115-151.

58. Egbuta MA, Mwanza M, Babalola O. Health risks associated with exposure to filamentous fungi. Int. J. Envi. Res. Pub. He. 2017;14:719.

59. Naga K, Suzuk K, Okada G. Studies on the distribution of alkalophilic and alkali-tolerant soil fungi II: Fungal flora in two limestone caves in Japan. Mycoscience 1998;39:293-298.

60. Doi S, Pinto A, Canali MC, et al. Density and diversity of filamentous fungi in the water and sediment of Araçá bay in São Sebastião, São Paulo, Brazil. Biota. Neotrop. 2018;18:1-9.

61. Obire O, Nwaubeta O, Adue BN. Microbial community of a waste-dump site. J. Appl. Sci. Environ. Manage. 2002;6:78-84.

62. Awasthi AK, Pandey AK, Khan J. Potential of fungus Trichoderma harzianum for toxicity reduction in municipal solid waste leachate. Int. J. Environ. Sci. Technol. 2017;14: 2015-2022.

63. Anastasi A, Tigini V, Varese GC. The bioremediation potential of different ecophysiological groups of fungi. In: Fungi as bioremediators. New York: Springer; 2013. p. 29-49.

64. Golan JJ, Pringle A. Long-distance dispersal of fungi. Microbiol. Spectr. 2017;5:1-24.

65. Gostinčar C, Grube M, De Hoog S, Zalar P, Gunde-Cimerman N. Extremotolerance in fungi: Evolution on the edge. FEMS Microbiol. Ecol. 2010;71:2-11.

66. Breza-Boruta B, Lemanowicz J, Bartkowiak A. Variation in biological and physicochemical parameters of the soil affected by uncontrolled landfill sites. Environ. Earth Sci. 2016;75:201. 67. Maier RM. Bioavailability and its importance to bioremediation. In: Bioremediation. Springer; 2000. p. 59-78.

68. Alexander M. Environmental and microbiological problems arising from recalcitrant molecules. Microbiol. Ecol. 1975;2:17-27.

69. Razarinah W, Zalina MN, Abdullah N. Utilization of the white-rot fungus, Trametes menziesii for landfill leachate treatment. Sains malays 2015;44:309-316.

70. Rodríguez-Couto S. Industrial and environmental applications of white-rot fungi. Mycosphere 2017;8:456-466.

71. Hosokawa R, Nagai M, Morikawa M. Autochthonous bioaugmentation and its possible application to oil spills. World J. Microbiol. Biotechnol. 2009;25:1519-1528.

72. Lakhtar H, Ismaili-Alaoui M, Philippoussis A, Perraud-Gaime I, Roussos S. Screening of strains of Lentinula edodes grown on model olive mill wastewater in solid and liquid state culture for polyphenol biodegradation. Int. Biodeterior. Biodegrad. 2010;64:167-172.

73. Alvarez PJ, Illman WA. Bioremediation and natural attenuation: Process fundamentals and mathematical models. Hoboken: John Wiley \& Sons; 2005. p. 1-25.

74. Koutrotsios G, Zervakis GI. Comparative examination of the olive mill wastewater biodegradation process by various wood-rot macrofungi. Biomed. Res. Int. 2014;2014:1-15.

75. Naveen BP, Sivapullaiah PV, Sitharam TG. Effect of aging on the leachate characteristics from municipal solid waste landfill. Jpn. Geotech. Soc. Spec. Publ. 2016;2:1940-1945.

76. Mousavi B, Hedayati MT, Hedayati N, Ilkit M, Syedmousavi S. Aspergillus species in indoor environments and their possible occupational and public health hazards. Curr. Med. Mycol. 2016;2:36-42.

77. Wheeler KA, Hurdman BF, Pitt JI. Influence of $\mathrm{pH}$ on the growth of some toxigenic species of Aspergillus, Penicillium and Fusarium. Int. J. Fo. Microb. 1991;12:141-149.

78. Schuster E, Dunn-Coleman N, Frisvad JC, et al. On the safety of Aspergillus niger-A review. Appl. Microbiol. Biotechnol. 2002;59:426-435.

79. Christensen TH, Kjeldsen P, Bjerg PL, et al. Biogeochemistry of landfill leachate plumes. Appl. Geochem. 2001;16:659-718.

80. Mukherjee A. Role of Aspergillus in bioremediation process. New Futur. Dev. Microbiol. Biotechnol. Bioeng. 2016:209-214.

81. Rani B, Kumar V, Singh J, et al. Bioremediation of dyes by fungi isolated from contaminated dye effluent sites for bio-usability. Brazilian J. Microbiol .2014;45:1055-1063.

82. Rasool A, Iruum S. Toxic metal effect on filamentous fungi isolated from the contaminated soil of Multan and Gujranwala. J. Bioresour. Manag. 2014;1:37-51.

83. Olukunle OF, Oyegoke TS. Biodegradation of crude-oil by fungi isolated from Cow Dung- contaminated soils. Nig. J. Biotechnol. 2016;31:46-58.

84. Gulzar T, Huma T, Jalal F, et al. Bioremediation of synthetic and industrial effluents by Aspergillus Niger isolated from contaminated soil following a sequential strategy. Molecules 2017;22:2244

85. Latiffah Z, Zariman M, Baharuddin M. Diversity of Fusarium species in cultivated soils in Penang. Malays. J. Microbiol. 
2007;3:27-30.

86. Liu R, Jiang X, Mou H, et al . A novel low-temperature resistant alkaline lipase from a soda lake fungus strain Fusarium solani N4-2 for detergent formulation. Biochem. Eng. J. 2009;46: 265-270.

87. Chulalaksananukul S, Gadd GM, Sangvanich P, Sihanonth P,
Piapukiew J, Vangnai AS. Biodegradation of benzo(a)pyrene by a newly isolated Fusarium sp. FEMS Microbiol. Lett. 2006;262:99-106.

88. Delsarte I, Rafin C, Mrad F, Veignie E. Lipid metabolism and benzo [a] pyrene degradation by Fusarium solani : An unexplored potential. Environ. Sci. Pollut. Res. 2018;25:12177-12182. 